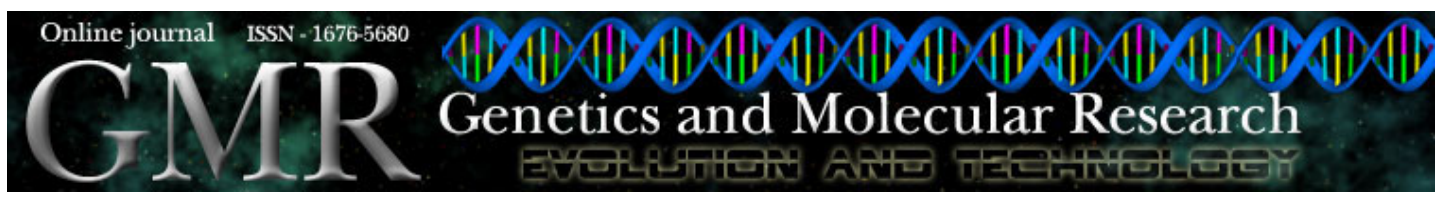

\title{
Evaluation of crosses of Holstein, Jersey or Brown Swiss sires x Holstein-Friesian/Gir dams. 2. Female liveweights
}

\author{
R.L. Teodoro ${ }^{1}$ and F.E. Madalena ${ }^{2}$ \\ ${ }^{1}$ EMBRAPA - Dairy Cattle, Juiz de Fora, MG, Brazil \\ E-mail: rteodoro@cnpgl.embrapa.br \\ ${ }^{2}$ Department of Animal Sciences, School of Veterinary Sciences, Federal \\ University of Minas Gerais, C.P. 567, 30123-970 Belo Horizonte, MG, Brazil \\ Corresponding author: F.E. Madalena \\ E-mail: fermadal@dedalus.lcc.ufmg.br
}

Genet. Mol. Res. 1 (1): 25-31 (2002)

Received January 10, 2002

Published February 28, 2002

\begin{abstract}
The liveweights of 100 females sired by Holstein $(\mathrm{H})$, Jersey (J) or Brown Swiss (BS) bulls out of Holstein-Friesian x Gir dams of $1 / 2$ to $3 / 4$ Holstein-Friesian fraction were compared. The animals were kept in a single herd under the same management. The data were analyzed separately for four age categories by least squares techniques. The models for cows and heifers older than 18 months included the fixed effects of breed of sire, Bos taurus fraction, season of weighing, days in milk class (for cows only), pregnancy status class, year and the random effect of animal nested within breed of sire $\mathrm{x} B$. taurus fraction subclasses. The models for younger heifers included the same effects except for lactation and pregnancy status. Based on 2937 observations, the mean weights for 0 - to 6-month-old calves for the groups with $\mathrm{H}, \mathrm{J}$ or BS sires were $88 \pm 1,77 \pm 1$ and $75 \pm 1 \mathrm{~kg}$, respectively, the mean weights for 1-year-old heifers were $168 \pm 2,159$ \pm 2 and $155 \pm 1 \mathrm{~kg}$, for 2 -year-old heifers, $327 \pm 4,303 \pm 4$ and $319 \pm$ $4 \mathrm{~kg}$, for 3-year-old heifers, $380 \pm 5,369 \pm 8$ and $390 \pm 4 \mathrm{~kg}$ and for cows, $464 \pm 3,413 \pm 2$ and $478 \pm 2 \mathrm{~kg}$. Cubic growth curves, which were different in the three sire breed groups, satisfactorily explained the cow weight changes with age $\left(\mathrm{R}^{2} \geq 0.98\right)$. Maximum weight was attained at 7.8, 9.5 and 9.2 years in cows with $\mathrm{H}, \mathrm{J}$ or BS sires. Although breed of sire effects were not significant in heifers $(\mathrm{P}>0.05)$, those with $\mathrm{H}$ sires were the heaviest up to two years of age. The females with BS or $\mathrm{J}$ sires had similar weights up to one year of age, but thereafter the former reached similar weights as the females with $\mathrm{H}$ sires and declined
\end{abstract}


less after attaining the maximum weight. The cows with $\mathrm{J}$ sires were the lightest at all ages. Since previous results showed similar protein and fat yields per day of calving interval in the three breed of sire groups, it is suggested that the lighter J crosses may be more economic than the other groups on account of their likely lower feed maintenance costs.

Key-words: Crossbreeding, Growth, Holstein, Jersey, Brown Swiss, Gir

\section{INTRODUCTION}

Cow liveweight has a strongly negative economic impact on farm profit because a high proportion of feed in dairy herds is required for maintenance. In a Brazilian study, reducing one percent the liveweights of dairy cows was more important than increasing the milk yield by one percent (Vercesi Filho et al., 2000). Description of liveweight changes with age is important for planning purposes and for evaluation of genotypes. Crossbreeding Bos taurus and $B$. indicus is a common long standing practice in Brazil (Madalena, 1998). Although the Holstein $(\mathrm{H})$ and the Gir are the most popular breeds, Jersey (J) and Brown Swiss (BS) are also locally available and a trial was set up to find out whether crossing with Jersey or Brown Swiss could further improve performance over the Holstein-Friesian (HF)/Gir crosses. The present study reports on the female liveweights of that trial. Results on dairy production and reproduction were previously presented (Teodoro and Madalena, 2002).

\section{MATERIAL AND METHODS}

\section{Animals and management}

A total of 2937 liveweights of 100 females were used in this study. These animals were the progeny of HF/Gir females of $1 / 2,5 / 8$ and $3 / 4 \mathrm{HF}$ fractions, randomly assigned to $\mathrm{H}$ (14), $\mathrm{J}(9)$ or BS (9) sires, mostly of USA and Canadian origin. A detailed description of the breeding values of these sires for milk yield and fat percentage was given by Teodoro and Madalena (2002). The experimental animals were born between 1977 and 1983, at the Santa Mônica Experimental Farm of the EMBRAPA-National Dairy Cattle Research Center, where they were managed together, in a single herd. Sixteen heifer calves were transferred from another farm between 6 to 12 months of age. There was no culling on yield but cows considered too old to stand a new lactation were culled. Non-pregnant heifers older than 33 months were culled.

The farm where the trial was conducted is located in the Municipality of Valença, State of Rio de Janeiro, in a hilly region at altitudes between 200 and $400 \mathrm{~m}$ over sea level. A description of the management was given by Teodoro and Madalena (2002). All animals were routinely weighed in January, April, July and October each year in the period of September 1977 to October 1993. Additionally, monthly weights of heifers were also available in 1977 and 1978. Dry cows and heifers were fastened for $16 \mathrm{~h}$ overnight before weighing (Madalena, 1964).

\section{Data analysis}

Data were analyzed separately for four categories: 1) heifer calves, up to 6 months; of 
age, 2) 1-year-old heifers (7 to 18 months); 3) heifers older than 18 months, and 4) cows. Numbers of records and ages in each group are shown in Table 1. Observations were grouped in quarterly seasons of weighing, five classes of pregnancy status ( $\leq 94-, 95$ - to $188-, \geq 189$-day pregnant, non-pregnant, and unknown, for cows culled) and four classes of days in milk $(\leq 120$, 121 to $240, \geq 241$ and dry).

Table 1. Ages and numbers of records in female categories.

\begin{tabular}{|c|c|c|c|c|c|c|c|c|}
\hline \multirow[t]{2}{*}{ Category } & \multirow[t]{2}{*}{ Animals } & \multicolumn{3}{|c|}{ Age (months) } & \multicolumn{3}{|c|}{ Records per animal } & \multirow{2}{*}{$\begin{array}{l}\text { Total } \\
\text { record }\end{array}$} \\
\hline & & Minimum & Maximum & Average & Minimum & Maximum & Average & \\
\hline Calves & 84 & 0 & 6 & & 1 & 5 & & 187 \\
\hline Young heifers & 98 & 7 & 18 & 11.7 & 1 & 9 & 4.1 & 404 \\
\hline Older heifers & 87 & 19 & 41 & 27.1 & 1 & 8 & 5.5 & 477 \\
\hline Cows & 75 & 28 & 185 & 86.3 & 1 & 49 & 24.9 & 1869 \\
\hline
\end{tabular}

Least-squares analyses were performed using Proc GLM of the SAS (1995) package. The models for cows and older than 18-month-old heifers included the fixed effects of breed of sire, $B$. taurus fraction, season of weighing, days in milk class (for cows only), pregnancy status, yearly age class and the random effect of animal nested within breed of sire $\mathrm{x} B$. taurus fraction subclasses. The models for the 1-year-old heifers included the same effects except those of lactation and pregnancy, with age in days as co-variable. F-tests were constructed from the expected mean squares for breed of sire and B. trurus fraction effects (Scheffé, 1959). Repeatability for each trait was estimated as $\mathrm{r}=\hat{\sigma}_{a}^{2} /\left(\hat{\sigma}_{a}^{2}+\hat{\sigma}_{e}^{2}\right)$, where $\hat{\sigma}_{a}^{2}$ and $\hat{\sigma}_{e}^{2}$ are the respective estimates of animal and residual variances. Polynomial weighted regressions of the least-squares means on age were separately estimated for each breed of sire up to the highest significant grade.

\section{RESULTS}

ANOVAs for each category are in Table 2 . The models considered accounted for a high proportion of the variation in weights in all categories. Breed of sire significantly affected weight of cows but not of heifers and the effect of $B$. taurus fraction was not significant in any category. Season effects were not significant for calves and older heifers but affected weights of cows and younger heifers. Pregnancy and lactation status also influenced the cow weights. Repeatability was high in all categories, particularly in cows.

The liveweight least-squares means for breeds of sire are presented in Table 3. Cows with BS sires showed higher average liveweight than cows with $\mathrm{H}$ sires, which in turn were heavier than those with J sires. Although differences between sire breeds were not significant in calves and heifers, calves and 1-year-old heifers with BS or J sires had lower means than the corresponding categories with $\mathrm{H}$ sires. The regression of weight on age for calves up to six months of age were $511 \pm 29,463 \pm 31$ and $406 \pm 31 \mathrm{~g}$ /day for the groups with $\mathrm{H}, \mathrm{J}$ and BS sires, respectively. The corresponding regressions for 1 -year-old heifers were $325 \pm 14,334 \pm$ 13 and $290 \pm 13 \mathrm{~g} /$ day.

The interaction between breed of sire and age, tested in preliminary analyses, was highly significant in cows $(\mathrm{P}<0.0001)$, indicating that the growth curves were different among the breed of sire groups. Cubic regressions on age fitted the yearly liveweight means of cows 
Table 2. ANOVA results for liveweights of females.

\begin{tabular}{|c|c|c|c|c|c|c|c|c|}
\hline & \multicolumn{2}{|c|}{$\begin{array}{c}\text { Calves } \\
(\leq 6 \text { months })\end{array}$} & \multicolumn{2}{|c|}{$\begin{array}{c}\text { Heifers } \\
\text { (1 year old })\end{array}$} & \multicolumn{2}{|c|}{$\begin{array}{c}\text { Heifers } \\
\text { (2 and } 3 \text { years old) }\end{array}$} & \multicolumn{2}{|r|}{ Cows } \\
\hline & d.f. & F-values & d.f. & F-values & d.f. & F-values & d.f. & F-values \\
\hline Breed of sire (S) & 2 & $0.59^{\text {ns }}$ & 2 & $1.24^{\mathrm{ns}}$ & 2 & $1.54^{\mathrm{ns}}$ & 2 & $10.66^{* *}$ \\
\hline B. taurus fraction $(\mathrm{F})$ & 2 & $3.04^{\mathrm{ns}}$ & 2 & $2.31^{\mathrm{ns}}$ & 2 & $0.63^{\mathrm{ns}}$ & 2 & $0.97^{\mathrm{ns}}$ \\
\hline Season & 3 & $0.27^{\mathrm{ns}}$ & 3 & $10.75^{* * *}$ & 3 & $1.66^{\mathrm{ns}}$ & 3 & $20.72^{* * * *}$ \\
\hline Age/breed of sire & $3^{\mathrm{a}}$ & $179.35^{* * *}$ & $3^{\mathrm{a}}$ & $521.63^{* * *}$ & $3^{b}$ & $65.38^{* * *}$ & $34^{\mathrm{b}}$ & $59.11^{* * *}$ \\
\hline Gestation status & - & - & - & - & 3 & $79.05^{\mathrm{ns}}$ & 4 & $39.66^{* * *}$ \\
\hline Days in milk class & - & - & - & - & - & - & 3 & $31.48^{* * *}$ \\
\hline Animal/S x F & 79 & $4.84^{* * *}$ & 93 & $7.26^{* * *}$ & 82 & $7.25^{* * *}$ & 70 & $85.16^{* * *}$ \\
\hline Error & 97 & & 300 & & 381 & & 1292 & - \\
\hline $\mathrm{R}^{2}$ & & 0.95 & & 0.90 & & 0.84 & & 0.89 \\
\hline C.V & & 10.46 & & 9.70 & & 9.95 & & 4.87 \\
\hline Error $\mathrm{SD}, \mathrm{kg}^{\mathrm{c}}$ & & 8.33 & & 5.41 & & 1.42 & & 21.81 \\
\hline Repeatability & & 0.64 & & 0.61 & & 0.54 & & 0.78 \\
\hline
\end{tabular}

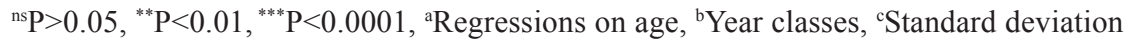

Table 3. Liveweight least-squares means (LSM) and standard errors (SE) for breeds of sire at selected ages.

\begin{tabular}{|c|c|c|c|c|c|c|}
\hline \multirow[t]{3}{*}{ Categories } & \multicolumn{6}{|c|}{ Breed of sire } \\
\hline & \multicolumn{2}{|c|}{ Holstein } & \multicolumn{2}{|c|}{ Jersey } & \multicolumn{2}{|c|}{ Brown Swiss } \\
\hline & LSM & SE & LSM & SE & LSM & SE \\
\hline Cows average & & & 112 & & & \\
\hline Cows, average & 404 & 3 & 415 & 2 & $4 / 0$ & 2 \\
\hline 3-year-old heifers & 380 & 5 & 369 & 8 & 390 & 4 \\
\hline 2-year-old heifers & 327 & 4 & 303 & 4 & 319 & 4 \\
\hline 1-year-old heifers & 168 & 2 & 159 & 2 & 155 & 1 \\
\hline$\leq 6$-month-old calves & 88 & 1 & 77 & 1 & 75 & 1 \\
\hline
\end{tabular}

in all three breeds of sire $(\mathrm{P}<0.05)$, accounting for almost all the variation in the least-squares means $\left(R^{2} \geq 0.98\right)$. The regression coefficients are shown in Table 4 and the predicted growth curves are in Figure 1. Only the J crosses had first calving at 2 years of age, as against 3 years in the $\mathrm{H}$ and $\mathrm{BS}$ crosses.

Table 4. Regression coefficients of cow liveweight least-squares means on age and standard errors (SE) for three breeds of sire.

\begin{tabular}{|c|c|c|c|c|c|c|}
\hline & \multicolumn{6}{|c|}{ Breed of sire } \\
\hline & \multicolumn{2}{|c|}{ Holstein } & \multicolumn{2}{|c|}{ Jersey } & \multicolumn{2}{|c|}{ Brown Swiss } \\
\hline & LSM & SE & LSM & SE & LSM & SE \\
\hline Intercept & 212.0856 & 15.9970 & $\overline{247.2888}$ & $\operatorname{ar} \overline{9510}$ & 240.4849 & 17.7812 \\
\hline Linear & 86.7783 & 7.2746 & 49.8277 & 7.2303 & 72.8995 & 7.6819 \\
\hline Quadratic & -8.7064 & 0.9978 & -4.1256 & 0.9841 & -6.6937 & 1.0176 \\
\hline Cubic & 0.2692 & 0.0421 & 0.1054 & 0.0410 & 0.1979 & 0.0419 \\
\hline
\end{tabular}

Genetics and Molecular Research 1 (1): 25-31 (2002) www.funpecrp.com.br 


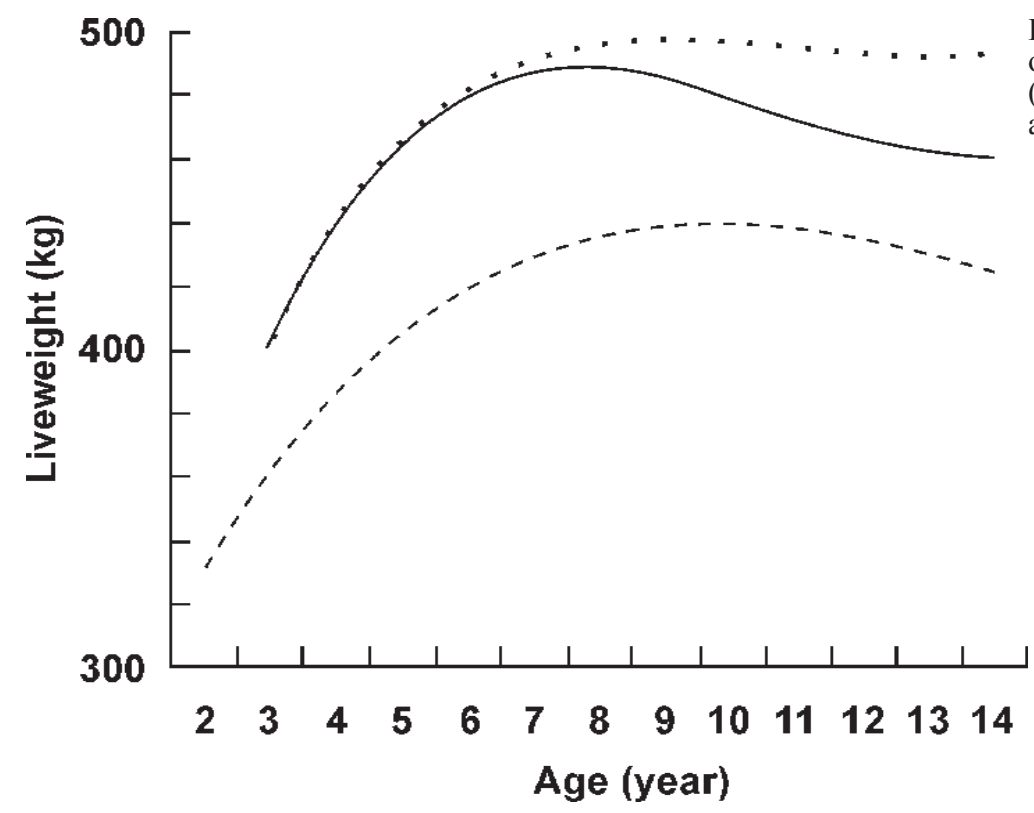

Figure 1. Growth curves of cows of three sire breeds: Brown Swiss (dotted line), Holstein (full line), and Jersey (broken line).

Liveweight of cows was lower in the first 120 days of lactation and increased thereafter. The effect of pregnancy-increasing weights of cows was apparent only in the classes above 94 days but not before (Table 5). Although statistically significant, seasonal effects were not important in cows, the least-squares means varying between $458 \mathrm{~kg}$ in April and $446 \mathrm{~kg}$ in October. Least-squares means for liveweights of 1-year-old heifers in trimesters 1 to 4 were, respectively, $154 \pm 2,164 \pm 2,165 \pm 2$ and $159 \pm 2 \mathrm{~kg}$.

Table 5. Cow liveweight least-squares means (LSM) and standard errors (SE) for lactation and pregnancy status classes.

\begin{tabular}{|c|c|c|c|c|c|}
\hline Days in milk & LSM & SE & Days pregnant & LSM & SE \\
\hline & \multicolumn{2}{|c|}{$\mathrm{kg}$} & & \multicolumn{2}{|c|}{$\mathrm{kg}$} \\
\hline$\leq 120$ & 444 & 2 & Non-pregnant & 441 & 2 \\
\hline 121 to 240 & 447 & 2 & $\leq 94$ & 443 & 2 \\
\hline$>240$ & 454 & 2 & $\overline{95}$ to 188 & 459 & 2 \\
\hline \multirow{2}{*}{ Dry cow } & 464 & 2 & $>188$ & 467 & 2 \\
\hline & & & Unknown & 451 & 1 \\
\hline
\end{tabular}

\section{DISCUSSION}

Description of traits up to advanced ages is important in Brazil because hybrid $B$. taurus/B. indicus cows show long herd lives (Lemos et al., 1996) which coincides with recommendations on economically optimum culling age (Cardoso et al., 1999). The growth curves of cows in this study were different for the three breeds of sire, with maxima at 7.8, 9.5 and 9.2 years in $\mathrm{H}, \mathrm{J}$ and BS, respectively, and local minima at 13.7, 16.6 and 13.4 years (the second value being outside the range of ages in the sample). 
Inspection of Figure 1 shows that the cubic regression was due to a slight increase in weight of the oldest cows. However, the numbers of old cows remaining in the herd were small ( 8 to 13 per breed of sire above 10 years of age). When data of old cows were discarded $(\geq 11$ years in the $\mathrm{H}$ or J sired groups, $\geq 10$ years BS sired group), the cubic term became not significant, i.e., regressions on age were quadratic. Quadratic growth curves peaking at 9 years of age were reported by Madureira et al. (2002) for HF x Guzera cows up to 10 years of age.

In comparisons of $\mathrm{H}, \mathrm{J}$ and $\mathrm{BS}$ crosses, several reports have indicated that $\mathrm{H}$ or Friesian $\mathrm{x} B$. indicus heifers were heavier than BS crosses and these heavier than $\mathrm{J}$ crosses at various ages and at first calving (Khanna et al., 1981; Koul et al., 1985; Pandey et al., 1985; Shrivastav et al., 1985, 1986; Chopra, 1990; Kumar et al., 1990). Also, several authors consistently reported heavier weights of the H crosses in comparison with J crosses (Shrivastav et al., 1986; Patel et al., 1987; Saha and Parekh, 1988; Singh et al., 1989; Chaudhry et al., 1993).

Notwithstanding those reports, slower initial growth of the females with BS sires relative to those with $\mathrm{H}$ sires, as found in the present study, was also reported by Katpatal (1983) in 12and 24-month-old heifers. In three-way crosses of J or BS sires with $\mathrm{F}_{1}$ Friesian x Gir cows, thus very similar to the crosses in this study, Saha and Parekh (1988) found the same weight at 12 months in both breed of sire groups and higher weight in the J sired group at 24 months. On the other hand, Khanna et al. (1981) reported that BS x F Friesian x Haryana were heavier than Jersey $\mathrm{x}$ (Friesian $\mathrm{x}$ Haryana) at six and 18 months of age. Thus, although the present results agree with the literature on $\mathrm{H}$ crosses being the heaviest and the $\mathrm{J}$ crosses the lightest, there are discrepancies on the growth pattern on the young females by BS sires.

Crosses in this trial had similar yields of milk protein and fat per day of calving interval (Teodoro and Madalena, 2002) which suggests that the J crosses may probably be more economic than the other two groups when the males are not reared, on account of their lighter weights and implied lower maintenance feed cost.

\section{REFERENCES}

Cardoso, V.L., Nogueira, J.R. and Arendonk, J.A.M. van (1999). Optimum replacement and insemination policies for crossbred cattle. Livest. Prod. Sci. 58: 95-105.

Chaudhry, M.Z, Wilcox, C.J. and Simerl, N.A. (1993). Factors affecting performance of Holstein and Jersey by Sahiwal crossbred dairy cattle in Pakistan. Rev. Bras. Genét. 16: 949-956.

Chopra, S.C. (1990). Comparative performance of halfbreds of Holstein-Friesian, Brown Swiss and Jersey with Hariana in semi-arid tropics. Indian J. Anim. Sci. 60: 93-96.

Katpatal, B.G. (1983). Raças e cruzamentos para a produção de bovino leiteiro nos trópicos: resultados experimentales. Anais do $1^{0}$ Simpósio Brasileiro de Melhoramento Genético de Bovino Leiteiro nos Trópicos, EMBRAPA-CNPGL, Coronel Pacheco, MG, Brasil, pp. 193-267.

Khanna, A.S., Jaiswal, U.C., Chopra, S.C. and Rathi, S.S. (1981). Genetic group differences for body weights at various ages in crossbred cattle. Indian J. Dairy Sci. 34: 345-347.

Koul, G.L., Pandey, H.N. and Katpatal, B.G. (1985). Studies on age at first calving and its relationship with weight and first lactational milk yield in crossbreds. Indian J. Dairy Sci. 38: 332-334.

Kumar, V.P., Rao, C.H., Venkatramaiah, A. and Naidu, K.N. (1990). Genetic group differences in the performance of the various crosses of Ongole with Friesian, Brown-Swiss and Jersey breeds. Indian J. Dairy Sci. 43: 46-50.

Lemos, A.M., Teodoro, R.L. and Madalena, F.E. (1996). Comparative performance of six Holstein-Friesian x Guzera grades in Brazil. 9. Stayability, herd life and reasons for disposal. Rev. Bras. Genét. 19: 259-264.

Madalena, F.E. (1964). Técnicas de determinación del peso vivo en los bovinos. Bol. Téc. Est. Exp. "Dr. Mario A. Cassinoni", Paysandú, Uruguay, 1: 49-54.

Madalena, F.E. (1998). Hybrid F Bos taurus $x$ Bos indicus dairy cattle production in the State of Minas Gerais, Brazil. Proceedings of the $6^{\text {th }}$ World Congress on Genetics Applied to Livestock Production, Armidale, 1998, 27: 199-202.

Madureira, A.P., Madalena, F.E. and Teodoro, L.R. (2002). Desempenho comparativo de seis grupos de cruzamento Holandês x Guzerá. 11. Peso e altura de vacas. Rev. Bras. Zoot. (in press).

Pandey, H.N., Srivastava, B.B., Nivsarkar, A.E., Taneja,V.K. and Garg, R.C. (1985). Weight and linear body measurements at calving. Indian J. Dairy Sci. 38: 250-255. 
Saha, D.N. and Parekh, H.K.B. (1988). Factors affecting body weights in half and three fourth crossbred cattle. Indian J. Dairy Sci. 31: 394-397.

SAS - Statistical Analysis System (1995). User's Guide. SAS Institute, Inc., Carey, NC, USA.

Scheffé, H. (1959). The Analysis of Variance. Wiley, New York, NY, USA.

Shrivastav, A.K., Katpatal, B.G. and Singh, C.S.P. (1985). Effect of genetic and non-genetic factors on growth rate in crossbred dairy cattle. Indian J. Dairy Sci. 38: 92-96.

Shrivastav, A.K., Katpatal, B.G. and Verma, S.K. (1986). Comparative studies on growth curve in crossbred female calves of Hariana x Friesian, Hariana x Brown Swiss and Hariana x Jersey. Indian Vet. Med. J. 8: 67-69.

Singh, R.V., Tewari, N., Singh, C.V. and Singh, Y.P. (1989). Genetic and non-genetic factors affecting the economic traits of first lactation in F1 crossbred cows. Livest. Adviser 14: 13-18.

Teodoro, R.L. and Madalena, F.E. (2002). Evaluation of crosses of Holstein, Jersey or Brown Swiss sires x HolsteinFriesian/Gir dams. 1. Dairy production and reproduction. Trop. Anim. Health Prod. (in press).

Vercesi Filho, A.E., Madalena, F.E., Ferreira, J.J. and Penna, V.M. (2000). Pesos econômicos para seleção de gado de leite. Rev. Bras. Zoot. 29: 145-152. 